\title{
Indigenous Yoruba Popular Music As An Agent For Socio Re-Orientation: An Examination of Saheed Osupa's Fuji Music
}

\section{Odetade Ibitayo, Fasinu Olusegun}

\begin{abstract}
This paper explores Fuji popular music as a tool for socialization within the current Yoruba cultural setting using the content exploration approach mode. Much of the traditional elements are embedded in the lyrics of Fuji musicians. Each Fuji musician digs experiments with the Yoruba culture to make the brand of Fuji music distinct from others. Saheed Osupa is a Fuji musician whose lyrics are laced with different sorts of Yoruba socio-cultural values. These values include proverbs, folktales, folklores, riddles, witty sayings, etc. The paper concludes that apart from being a vibrant art form in the popular literature sub-genre, the contents of the Fuji music can also serve pedagogical and other educational purposes in the present-day setup.
\end{abstract}

\section{Keywords}

Indigenous Music, Socialization, Fuji Music and Socio-cultural values. 


\title{
Indigenous Yoruba Popular Music As An Agent For Socio Re-Orientation: An Examination of Saheed Osupa's Fuji Music
}

\author{
Odetade Ibitayo, \\ Fasinu Olusegun
}

\section{Introduction}

The concept 'Education' means different things to different people. There is no single generally accepted definition of education. Mercy Fasehun argues that education does not mean teaching people to know what they do not know; it means teaching them to behave well(76). This signifies that the worth of an individual cannot be measured in terms of the number of the acquired certificates but in terms of the number of the acquired skills cum moral rectitude. Hence, education cannot be separated from culture; it is not a mere transmission of a body of knowledge about society from generation to generation but involves agglomeration of the total social inheritance and way of life which is being transmitted to the upcoming generation.

African traditional education is an education that usually starts from infancy when the child begins to learn how to talk, eat and to do other things pertaining to his culture. It proceeds informally as children gather from time to time around an elder who impacts into them certain moral and intellectual values through the use of oral traditions. Olagunju citing Osokoya stresses that African traditional education is an education that helps the Africans in transmitting their culture, traditions and experiences from generation to generation(66). It helps them to explore and exploit their environment. Nevertheless, Fafunwa condemns the general notions of some poorly-informed writers who see traditional education as primitive - even savage and barbaric (89). Traditional education, according to Fafunwa, is all-embracing; involving educational activities and skills necessary for effective citizenship in the child community.

The objectives of traditional education are directed towards the production of useful and productively independent individuals who will assume responsibilities in the community. African traditional education curriculum includes ethnic behavior, self- 
respect, self-confidence, hard work and honesty, faithfulness, folklore and orature, truthful and character building, obedience, and useful trade of the community. Onwuchekwa posits that African traditional education is an education of involvement; of participation, of activity, and education that involves discovery (46). Ibukun identifies four stages of African indigenous (traditional) education:Infancy, Childhood, Young Adult, After Age 26(58). The mother is the main teacher while the child learns from father, siblings, peers and other members of the society such things as language training, socialization and general behavior. The child is introduced to learning through imitation and agents of teaching such as music. The child is introduced to an apprenticeship. The adult is free to practice on his own. However, it is important to state that the main objective of African traditional education is character building. Character training is the main purpose and focus of all the processes of socialization in African traditional education.

Yoruba society is ultimately focused on producing well-behaved individuals. This is the reason why the Yoruba refer to a person of a good character as "ọmoluabi" that is "one who behaves as a well-born". This paper aims to highlight the indigenous (traditional) values of the Yoruba people inherent in the music of Saheed Osupa, a popular Fuji musician who is widely known for using his brand of Fuji music to passing across the values, beliefs, ideas, and attitudes of the Yoruba people. African traditional education is aimed at propagating traditional values. Wande corroborates this opinion when he states that "Good character is the cornerstone of traditional education among the Yoruba" (384).

Western education has ruled over traditional education. Town life has brought great moral laxity and neglect of traditional morality. African traditional values, like greeting and respect of elders, have been submerged by a foreign culture. The value that Yoruba placed on character training has been influenced by the nature of Western education. The traditional role of the family is character - training and socialization of the young ones.

Based on the above discussion, it is revealed here that good character is the central theme of African traditional values. The values include chastity, hospitality, truth and rectitude, unselfishness, covenant-keeping, honor, and respect for seniors. Various approaches are adopted to inculcate these values in the young ones even after exposure to Western education. Music as one of the agents of socialization is adopted for this study. Fuji musicians like Saheed Osupa can be seen as an orientalist who uses his brand of Fuji music to impact right values, attitudes, culture and also a good character which is the cornerstone of Yoruba traditional education.

Most songs of Saheed Osupa ignite a sense of passion in the mind of every youth who is willing to learn about Yoruba culture, society, and history. Music has always been an important part of every society because every story told under a tree in a moonlight scene entails songs that build characters and spring up positivity in children. Saheed Osupa's songs entail oral tradition like folklores, proverbs, myths, superstitions and the likes. Stories are embedded in his songs which pass across didactic messages creating 
culture and tradition within minds. Songs of Saheed Osupa enlightens both young and old minds about the virtue of truth and honesty which is believed to prevent youth from dying young. Honor and respect are also emphasized and preached in Saheed Osupa's songs. Saheed Osupa envisages honor and respect for elders and those in the position of authority.

\section{Popular Music: An Overview}

The term 'popular music' has been variously defined. One of its most distinctive features is that it is often associated with the common people. The people are at the center of its discourse. Popular arts are important in the lives of people. Barber, while commenting on the importance of popular arts, opines that people too poor to contemplate spending money on luxuries do spend it on popular arts, sustaining them and constantly infusing them with life (2). According to Adedeji, popular music has gone beyond being viewed or interpreted only as an art and is now seen as representing more than that because in it are embedded strands of messages that represent the way the artist wants to be seen or who he is representing or what he stands for(35). Taking a cue from Adedeji's definition, popular music contains messages that portray what the artist intends to pass across to his numerous audiences while at the same time, projecting the artist's perspective about life in general. Omibiyi regards popular music as a corpus of music that is widely accepted and commonly liked by the masses while its popular acceptance is usually overtly demonstrated by large-scale participation (152). It is usually created especially for commercial purposes, but to provide entertainment. Again, the centrality of the masses is attested to in this definition. Any popular art, from music to graffiti, cartoon and so on, must be generally accepted by the masses before it can be termed popular. It is the participatory attitude of the common people that makes a popular art to be termed 'popular' or generally acceptable.

In Yoruba public sphere, the performance of any popular arts must be done within a particular social context. No performance can exist in a vacuum. Just as art is never created in a vacuum, a literary work to be relevant should bear "relevance, explicitly or implicitly, to the social milieu in which it is set" (Kehinde 87). This is in tandem with Euba's opinion where he describes popular music as those associated with nightclubs or with private parties or other social contexts in which merriment (àríyá), leisure and consumption of beverages are prime objectives(5). From Euba's definition, entertainment takes a significant place in popular music. In this process of entertainment, commercialization sets in. Entertainment provides the context within which popular music can easily be understood, experienced and enjoyed without the popular musician having formal or any specialized music training.

However, popular music is not for entertainment alone. It has also been used to serve as a form of protest and revolutionary measure against oppressive regimes in Africa and beyond. Fela Anikulapo-Kuti, while alive, used songs to criticize political injustice both in Nigeria and beyond. Fela's album "Zombie" was a vituperative attack on Nigerian soldiers using the Zombie metaphor to describe the methods of the Nigerian 
military. The album infuriated the government and a vicious attack was set against the Kalakuta Republic (Fela's shrine). Fela was severely wounded and his elderly mother was thrown from a window, causing fatal injuries. The encounter eventually led to his mother's death. Olaniyan asserts that:

[...] key to approaching the music of Fela and the contexts of its production, circulation, and consumption. It reveals, for example, the peculiar character of the relations between art, especially oppositional music, and a post-colonial African state. It is also an inadvertent homage to that part of Fela's image as a musician that is most familiar to the world: the "political". Above all, the unvarnished crudity, unhidden ill-bred megalomania, killjoy morbidity, and sheer incredibility of the unusual command speak volumes about the political order - and those who manage and profit from it on behalf of which it is uttered. (2)

Following this line of thought, Adegoju regards a musician as an archivist of sort who, through his music, probes into the past and present situation of his people(3). Using Lagbaja as an example, he opines that "Lagbaja's musical form and the social relevance of his message have endeared him to both the young and old". While Adegoju portrays Lagbaja as an archivist, Adegoke sees him as an "Afrocentrist and Black historian whose themes transcend Nigeria, and even the entire Black community (the Diasporas and the Americas)" (157).

Emielu considers popular music as a source of youth empowerment in Nigeria(8). He further stresses that popular music can serve as a source of employment to the youths in Nigeria. The youths can be engaged in singing, recording, and the marketing of popular music. This will boost the economy of the country if properly handled. Popular music can also be seen as a proper channel for wealth creation. In regard to the consumption pattern of popular music, Englert opines that

The mass factor is of course more relevant as even though few may actually buy music on the market - it certainly reaches out to the so-called masses through the media, first and foremost the radio, but also television and increasingly also the internet. The liberalization of radio and TV helped facilitate the emergence of new forms of popular culture which did not have space on the usually state-controlled media.(3)

Hence, the mass media can be said to play an important role in the propagation of popular music. Oyebamiji, therefore, makes a classification based on Yoruba traditional music (517). The classification is (1) Religious music (2) Social music. He says "religious music is used during indigenous religious festivals in worshipping gods and entertaining the celebrants and their visitors" while "social music is based on entertaining 
people during social activities, festivals and engagements". Today, religious music still exists, and there are some elements of this traditional religious artifact in both old and contemporary music genres.

The people are the key factor in determining the popularity of a song. They can be referred to as those who process these songs by listening and extracting the areas that attack the 'ills' in an individual's life and the society at large. Another important issue is that the theme of music termed 'popular' must be familiar. It must engage contemporary events and happenings in society.

\section{History of Fuji music}

The origin of Fújì music can be traced back to the Muslim Ramadan fasting period when it was used to wake up faithful Muslims 1 . The introduction of Islam to Nigeria has its dire consequences on the music of the people. One thing that is common to both Fújì and Juju music is their ability to accommodate foreign instruments. Olaniyan observes that "Fújì, as a genre, is well known as the music of Muslim Yoruba as it is very much influenced by Islam" (23). He further stresses that "it was quite evident that Islam did not welcome much use of music and dance in their mode of worship except the use of their Quranic recitation" (Olaniyan 87). As regarding the legality and illegality of Islamic music, Raji notes that "songs in itself is lawful but it becomes unlawful (Haram) abominable (Makruh) and laudable (Mustahab) according to time, circumstances, places, motive and kinds of songs" (240). In this contemporary age, we observe that Islamic songs have been used to propagate the ideals of the religion. Examples of music forms that originated from Yoruba Islamic tradition include sẹ́lí, wákà, wéré, àpàlà, sákárà and fújì. Wéré reigned before the advent of Fújì music. Olaniyan (2007) opines that:

Wéré was the brand of music used to wake Muslims at dawn to eat their early morning meal in preparation for their fast during the month of Ramadan. This meal is called "sààrì" by the Yoruba. The musicians involved are called ajísàrì, meaning he who wakes up people to eat sààrì.

Adedeji also notes that:

Fújì is a category of music that originated from Yoruba musical practice and culture, and its language of delivery is Yoruba. For any artist to be classified as a Fújì artist, his mode of delivery must be primarily Yoruba, while artists in other genres that want to appropriate Fuji in their music also must use Yoruba language for that part.(32)

Alhaji Sikiru Ayinde Barrister and Alhaji Kollington Ayinla were both wéré musicians in the 1950s. The early singers of Wéré/Ajísàrì music before the emergence of 
the likes of Barrister were singers like Baba Ralia, Saka Laigbade, Captain Muniru Mayegun (Baba Wasiu) from Isale Eko, Ajadi Ganiyu from Oluwole, Kasali Alani (Jolly Lawa) from Ita-Alagba. According to Olowoseunre, Sikiru Ayinde Barrister started his wéré music performance at Masewele in 1958 with his brother, Yekinni, who was then playing Sakara before, he moved to Odi Olowo. Over the years, Alhaji Sikiru Ayinde Barrister has been widely credited with the creation of Fújì music. In one of the interviews that Barrister granted before his demise, Olowosunrere quotes:

By the time I was working on my new experiment (Fújì), I took cognizance of the circumstances that led to the new development and my environment and the Fuji Mountain in Japan which is the mountain of love and peace. Fuji is music of love and peace, hence, I gave it that name. (73)

The following musicians also took part in the development of Fújì music: Ayinde Muniru Mayegun, Kau Aminu, Saka Layigbade, Mufu Lawal, Ayinde the Law, Ajadi Lawal, Jibowu Barrister, Kasali Alani Jolly, Abinuwaye Basiru, Late Dauda Akanmu Epo Akara and Akande Monsuru. He notes that Fújì music changed when it got to the turn of Dr. Sikiru Ayinde Barrister and Ayinla Kollington Baba Alatika. Therefore, this paper supports the view that there were Fújì musicians before Sikiru Ayinde Barrister. Wasiu Ayinde notes that it was Barrister who transformed Fújì music.

\section{Biography of Saheed Osupa}

Saheed Akorede Okunola popularly known as Saheed Osupa is an esteemed Nigerian Fuji musician born in Ajegunle in 1969 to late Alhaji Moshoodi Okunola an Etiyeri musician. Saheed Osupa started music in early 1983. Osupa attended Polytechnic of Ibadan where he had his OND in 1992 and later went to study Computer Networking in USA. He is a notable actor in the Nigerian Film Industry. His albums include Fuji Fajisco, Fuji Blues, Fuji Demonstration, Master Blaster, Stainless Fuji, Big Daddy, African Delight, Reliable, Endorsement, Mr. Music, Barrybration, Transparency and Transformation.

\section{Analysis}

Saheed Osupa also makes use of proverbs and witty sayings to illustrate the virtue of good behaviour and also warn against social vices. Some of the songs are analyzed below

$\begin{array}{ll}\text { İdá nikó } & \text { You reap whatever you contribute } \\ \text { Àjọ nìwà } & \text { Behaviour is a daily contribution } \\ \text { Kì sèébú } & \text { This is not an abuse } \\ \text { Oun to bá dá } & \text { Whatever you contribute } \\ \text { Lo maa kó } & \text { You will get in return }\end{array}$


In the song above, Saheed Osupa makes ample use of proverbs to create the image of good behaviour. Omolúàbí/Good virtue is compared to daily contribution. Àjo is a Yoruba way through which people engage in daily, weekly and monthly contributions of money. Whenever it is someone's turn, all the people in the group are expected to contribute for the appointed person. Behaviour is portrayed in this song as a daily contribution, whatever you contribute is what you will get in return. This can also be termed as the law of Karma or retributive justice.

$\begin{array}{ll}\text { Wón nímú ní kà } & \text { They say the nose is wicked } \\ \text { Kì gbóò̀n èyàn ibi } & \begin{array}{l}\text { It does not perceive the odour of a } \\ \text { wicked person }\end{array} \\ \text { Àwon kan dè lè ní } & \begin{array}{l}\text { Some may say } \\ \text { Só gbóórùn èyàn ire gan }\end{array} \\ & \begin{array}{l}\text { Does it even perceive the odour of a } \\ \text { good person }\end{array} \\ \text { Yorùbá mà káre fówe pẹlú ogbọnn } & \begin{array}{l}\text { Yorubas are people with proverbs } \\ \text { and wisdom }\end{array}\end{array}$

There is another use of proverb here. The nose is one of the sensory organs which is capable of sensing odour or smell. Nose as used in the song above is portrayed as a full human being who is wicked. Nose ordinarily cannot smell an abstract object. This means a wicked person will be shown by his/her behaviour in the public. This proverb portrays the ingenuity of the Yorubas.

$\begin{array}{ll}\text { Ojú larí } & \text { We can only see the facial expression } \\ \text { Oré ò dénú } & \text { Friendship does not go deep down } \\ \text { Tó bá ń dùn } & \text { If it is rossy } \\ \text { Wọ́n á bá ẹé } & \text { They will eat with you } \\ \text { Tó bá kan } & \text { If it turns sour } \\ \text { Wọ́n á sá } & \text { They will run away }\end{array}$

This is also another use of proverb. The Yorubas use this proverb to checkmate the dynamic nature of human beings generally. Some people stay with their friends when they financially okay while they desert them when the situation worsens. Saheed Osupa again lays emphasis on the virtue of good friendship. The story motif is also prominent in the songs of Saheed Osupa. This is one of the avenues through which education takes place in traditional Yoruba land. It usually takes place under the tree in the evening when everyone especially the children might have come back from their daily chores. The storyteller is usually an elder while the children serve as the audience. The essence of this storytelling period is to educate the children on what is morally upright in the society. One of such songs is stated below.
İgà ìpónjú là ń mòré
We know friends in times of tribulation
Kà jọ fòkèlè run bè
Let us use a wrap to touch soup 
Ká tún jo fòróró jẹsu

Se rọ̀rẹ méjì kan ńgbà kan

Wón jìjo wà

Wón ń peja

İkan mà lowó è dẹ

İkeji lowo ò de

Sewá rí èyí tọ́wọ ẹ de

To ń fún ikeji je

Bó tì è jẹ asin ló ń pa nígbà yẹn

Síbèsíbẹ wón ń pin je

Ni tèyi tọ́wọ́ ẹo de

Kèrèkẹrè lowọ ẹ ń de

Ó ti wá fẹ di gbéraga

Àwon tí ó rí nígba yẹn

Ló wa ñ pẹ kó wá jẹja

Tán bá dẹ ti wá jeja

Wọn á máayo òrẹe è yẹn
We should also use oil to eat

Two friends sometimes ago

They were together

They are into fishing business

Only one of them was catching fish

The second one could not catch a fish

The one that was able to catch fish

Was giving it to his partner

Even though he was killing a small fish

They were still sharing it together

The one that was not able to catch fish

Little by little he was catching fish

This change of status has turned to pride

Those he didn't see when he was passing through challenges

Were the ones he was calling to eat fish with him

When they eat the fish

They will start making jest of his friend

This song above portrays the image of two friends who are fishermen. The first fisherman does catch fish while the other could not even though they were professionals. Things turned around later on and the one that could not catch a fish started doing so. He forgot his friend that helped him in time of need. In a short while, he started giving his good catch to people to those that were not there while his friend was helping him. Again, Saheed Osupa lays emphasis on the virtue of Omoluabi in friendship. The Yorubas see friendship as a covenant that must be well protected. As stated in the song, Igba Iponju la $\mathrm{n}$ more/A true friend is known in times of trouble. Friendship will stand the test of time when two friends can stand and stay with each other in times of trouble. This is clearly portrayed in the song. When the second friend could not catch fish at all, the other stayed with his partner by even sharing with him from his proceeds. The first was betrayed by the second when there was a swing in the course of nature. Saheed Osupa in this story depicts the course of true friendship and also teaches his audience not to be a betrayal.

Torí tí ọrẹ méji

Bá jo wo yàrá sọrọo

Tán jo rojú jáde

Wọ́n ti jọ sòótó fún ra

Sùgbón tán bá rẹin jáde

Òtító kọ́ ni wọ́n wo yệù sọ
If two friends

Enter a room to discuss

If they come out frowning their faces

Truth has been told to each other

But if they laugh while coming out after discussing

They have not entered the room to discuss the truth 
The Yorubas believe in the sanctity of truth. Truth is seen as an important aspect of a person that is recognized as Omoluabi. It is the cornerstone of character training in Yoruba society. Right from the cradle in Yoruba land, children are taught to speak the truth always. Thus, a popular saying in Yoruba land says Otito koro/Truth is bitter. Truth is likened to a bitter pill. It does not always go down well with people. In the excerpt above, the picture of two friends is created. The two friends portrayed here do not necessarily mean friends all the time, it could be children of the same mother. Thus, in another way round, Yorubas do say Tomo iya meji ba wo yara soro/If two children of the same mother enter their abode to discuss an issue. In Yoruba land, it is assumed that if two people enter a room to discuss a matter, if they frown their faces while coming out, it is believed that truth has been told to each other. Roju/Frown in its literal sense connotes unhappiness. If it is the other way round, they have just deceived themselves.

\section{E bá jẹ ká jórúko \\ Tó dùn síle domo wa \\ İwà tọmo bá ká mó wa lọ́wọ}

Ló máa hù
Let's bear a name

That is good for our children The behavior our child knows us with

That is how he/she will behave

Oruko/name is very important in Yoruba land. It is an identity that must be protected. Oruko as used in this context represents a legacy. It can also be termed as a behavior that can either be good or bad. Omoluabi is the cornerstone of a good name. Whatever an individual or a parent does, the children or the generation after will reap the fruits of such behavior. Right from the cradle, children are taught to exhibit good behavior wherever they find themselves. In the song above, the artiste presents two different contexts. First, the artist depicts a situation within which we must exhibit good behavior because our children or generation after will reap the fruit of such behavior. The second context represents a situation within which whatever a parent does become a legacy that the children or the next generation will later propagate in the future. As earlier stated in this study, the song above again reinforces the virtue of Omoluabi which must be taught as a lesson to all and sundry in society. A Yoruba proverb also supports this view, Oruko rere leso eniyan/Good name is the beauty of an individual.

\section{Conclusion}

Indigenous music can serve as a means of educating the people especially the young ones. This paper examined the significant role of music as an agent of change in society by emphasizing the enormous impact of Fuji music and also established that musicians act as agents/tools for socialization rather than mere entertainers. The Fuji music of Saheed Osupa was used to buttress this point of view. The virtue of Omoluabi is high extolled in the Yoruba traditional society and this can in turn be inculcated into 
the curriculum of primary, secondary and even tertiary education in Nigeria at large. This will further give birth to an efficient and effective society where everyone can live peacefully without any fear of insecurity cum sociopolitical problems.

\section{Discography}

Saheed, Osupa. Big Daddy. Lagos: Mosebolatan Music, 2003.

Saheed, Osupa. Respect and Reliable. Lagos: Mosebolatan Music, 2015.

Saheed, Osupa. Transparency. Lagos: Mosebolatan Music 2005

Wasiu Ayinde. Flavour 1. Lagos: Omega Music, 2005.

\section{Works Cited}

Adedeji, Adewale. "Yoruba Culture and its Influence on the Development of Modern Popular Musicin Nigeria". Ph.d Thesis, The University of Sheffield, 2010. http://etheses.whiterose.ac.uk/2257/, Accessed February 24, 2021.

Adegoju, Adeyemi. “The Musician as Archivist: An Example of Nigeria's Lagbaja”.

Itupale Online Journal of African Studies, Vol. 1, 2009, pp. 1-23. http://www.jpanafrican.com/docs/vol.1no9/, Accessed March 20, 2021.

Adegoke, Adetunji. "Language and Identity Representation in Popular Music". Journal of Innovative Research, Issue 1, 2011. http://dukejournals.org/cgi/reprint/8/3/441, Accessed March 25, 2021.

Barber, Karin. "Popular Arts in Africa”. African Studies Review, Vol. 30, no. 3, 1987, pp. 1-78.http://links.jstor.org/sici? Accessed March 22, 2021.

Emielu, Austin. "Popular Music and Youth Empowerment in Nigeria". Conference Proceedings ofThe Professor Femi Osofisan International Conference on Performance, 2008.

Englert, Birgit. "Popular Music and Politics in Africa - Some Introductory Reflections". WienerZeitschrift fur Kritische Afrikastuden Nr. Vol. 14, no. 8, 2008, pp. 1-5 http://www.researchgate.net/, Accessed April 20, 2021.

Euba, Akin. "The Interrelationship of Poetry and Music in Yoruba Tradition". Yoruba Oral Traditions. Edited by Wande Abimbola, Ife African Literature and Languages Series, 1975, 471-483.

Fafunwa Babatunde. History of Education in Nigeria. London: George Allen and Unwin, 1974.

Fasehun, Mercy. "Towards Integrating the Principles of African Traditional Education into Teacher Education". The Management of Tertiary Institutions for Qualitative and Functional Education in Nigeria. A Festschrift in Honour of Professor Adyemi IbukunOluwa Idowu Edited by O. Atoyebi et al, Alafas Nigeria Company, 2013.

Ibukun O. History of Education and Educational Development in Nigeria. Lagos: Green Line Publishers, 1996.

Kehinde, Ayo. "Rethinking African Fiction in the Era of Globalisation: A Contest of 
Text and Context". Journal of Nigeria English Studies Association. Vol. 6, no. 1, 2005, pp. 81-100.

Olaniyan, Tejumola. Arrest the Music! Fela and His Rebel Art and Politics.

Bloomington: Indiana University Press, 2004

Olaniyan, Yemi (2007). "The Evolution and the Techniques of the Creativity in Fuji: A

Nigerian PopularMusic Genre". African Musicology Online. Vol. 1, no. 2, 2007,

pp. 22-31. http://www.africanmusicology.com/vol.1\&20no2html, Accessed

February 15, 2021.

Olagunju A. M. "Traditional System of Education in Africa". African Culture and

Civilization. Edited by S. Ademola Ajayi. Ibadan: Atlantic Books, 2005, pp. 22-

35 .

Olowoseunre, Abiodun. An Applause for a Lyric Performer: Late Chief (Dr.)

Mohammed Sikiru Ayinde Balogun. Lagos: Great Nation Publication, 2011.

Omibiyi, Mosunmola. "Popular Music in Nigeria". Jazzforschung. Vol. 13, 1981, pp. 309-320.

Onwuchekwa J. N. "Traditional Education: An Asset to Formal Education”. Obayan P.

A. I (ed.) Education and the Nigerian Society. Ibadan: Ibadan University Press, 1981, pp. 210-228.

Oyebamiji, Mustapha. “A Literary Appraisal of Sakara. A Yoruba Traditional Form of

Music”Yoruba Oral Traditions. Edited by Wande Abimbola, 1975, pp. 517-549.

Raji, Sulaymon. "The Legality of Music in Islam". Journal of the School of Languages,

Adeyemi College of Education, Vol. 2, 2004, pp. 235-240.

Wande, Abimbola. Iwapele: " The Concept of Good Character in Ifa Literary. Yoruba

Oral Tradition: Poetry in Music, and Dance. Edited by Wande Abimbola, Ife:

O.A.U. Press, 1975, pp. 225-248.

\section{The Authors}

\section{Odetade Ibitayo}

Department of English,

Adeyemi College of Education,

Ondo, Nigeria.

E-mail: odetadeio@aceondo.edu.ng

\section{Fasinu Olusegun}

Department of French,

Adeyemi College of Education,

Ondo, Nigeria.

E-mail: faseg2001@yahoo.com 


\section{The Article}

Date sent: 01/05/2021

Date revised: 12/07/2021

Date Accepted: 14/07/2021 